\title{
Construction of bacterial artificial chromosome (BAC) libraries of banana (Musa acuminata and Musa balbisiana)
}

\author{
Pietro PIfFANelli ${ }^{1,4}$, Alberto D. VILARINHOS ${ }^{2}$, Jan SAFAR ${ }^{3}$, Xavier SABaU ${ }^{1}$, Jaroslav Dolezel ${ }^{3}$
}

${ }^{1}$ Cirad-Bios, UMR DAP, av. Agropolis, TA A-96 / 03, 34398 Montpellier Cedex 5, France

xavier.sabau@cirad.fr

2 EMBRAPA Cassava Trop. Fruit Crop., Embrapa Str., Cruz das Almas, BA, 44380-000, Brazil

vila@cnpmf.embrapa.br

${ }^{3}$ Lab. Mol. Cytogenet. Cytom., Inst. Exp. Bot., Sokolovska 6, CZ-77200 Olomouc,

Czech Republic

dolezel@ueb.cas.cz

${ }^{4}$ Parco Tecnol. Padano, Via Einstein, 26900 Lodi, Italy pietro.piffanelli@tecnoparco.org

${ }^{*}$ Correspondence and reprints

Fruits, 2008, vol. 63, p. 375-379 (c) 2008 Cirad/EDP Sciences All rights reserved DOI: $10.1051 /$ fruits:2008037 www.fruits-journal.org

\begin{abstract}
Construction of bacterial artificial chromosome (BAC) libraries of banana (Musa acuminata and Musa balbisiana).
\end{abstract}

Abstract - Introduction. This protocol applies to the characterization of genome structure and evolution of M. acuminata and M. balbisiana genomes; construction of physical maps around markers of interest and QTLs; comparative genomic studies with other monocot species; and study of banana streak virus (BSV) integration patterns in banana nuclear genomes. The principle, key advantages, starting plant material, time required and expected results are presented. Materials and methods. This part describes the required materials, and the protocols for isolation and lysis of banana nuclei; high-molecular-weight (HMW) DNA Hind III digestion and pulsed-field gel electrophoresis (PFGE) analysis; large-scale HMW DNA Hind III digestion and ligation to the pINDIGOBAC-5 vector; and analysis of recombinant BAC clones. It mentions the main problems which can occur. Results. The described protocols will enable the efficient construction of BAC libraries from Musa species. These libraries can be used to construct physical maps and select specific genomic regions to be sequenced.

France / Musa sp. / methods / electrophoresis / DNA / genetic markers / genetic maps

Construction de bibliothèques de chromosomes artificiels de bactérie (BAC) de bananier (Musa acuminata et Musa balbisiana).

Résumé - Introduction. Le protocole s'applique à la caractérisation de la structure du génome et à l'évolution des génomes de $M$. acuminata et de $M$. balbisiana ; à la construction de cartes physiques autour des marqueurs d'intérêt et des QTLs ; aux études de génomique comparative avec d'autre espèce de monocotylédones ; à l'étude des modèles d'intégration du virus BSV dans les génomes nucléaires de la banane. Le principe, les principaux avantages, le matériel végétal utilisé, le temps nécessaire et les résultats attendus sont présentés. Matériel et méthodes. Cette partie décrit le matériel de laboratoire nécessaire, et les protocoles permettant l'isolement et la lyse des noyaux de cellules de bananier ; la digestion Hind III de ADN à haut poids moléculaire (HPM) et l'analyse électrophorèse sur gels à champ pulsé ; la digestion Hind III à grande échelle de ADN à HPM et ligation au vecteur pINDIGOBAC-5 ; l'analyse des clones recombinants de BAC. Elle mentionne les principaux problèmes pouvant se poser. Résultats. Les protocoles présentés permettent de construire des bibliothèques de BAC à partir d'espèces du genre Musa. Ces bibliothèques peuvent être utilisées pour construire des cartes physiques et sélectionner des régions du génome à séquencer.

France / Musa sp. / méthode / électrophorèse / ADN / marqueur génétique / carte génétique 


\section{Introduction}

\section{Application}

The protocol applies to:

- characterization of genome structure and evolution of Musa acuminata and Musa balbisiana genomes,

- construction of physical maps around markers of interest and QTLs,

- comparative genomic studies with other monocot species (e.g., rice, sorghum, oil palm) [1],

- study of banana streak virus (BSV) integration patterns in banana nuclear genomes [2],

- sequencing of selected regions of the Musa genome [3, 4] and systematic sequencing of nuclear, mitochondrial and chloroplast genomes.

\section{Principle}

Banana nuclei are isolated from leaf tissues using a modification of the protocol developed by Zhang et al. [5] to eliminate high levels of polyphenols [6] and polysaccharide contaminants or using a flow sorting approach [7]. High-molecular-weight (HMW) DNA is then released from the nuclei by mild lysis and partially digested with the restriction enzyme Hind III. Pulsed-field gel electrophoresis is employed to separate banana HMW genomic DNA and the region covering fragments between (100 and 300) kbp is then dissected out. Then, by electroelution [8], the high molecular genomic DNA $(100-300 \mathrm{kbp})$ is recovered and ligated to the Hind III dephoshorylated BAC vector pIndigoBAC-5. The size of the resulting recombinant bacterial artificial chromosomes (BACs) containing banana genomic DNA fragments is visualized by NotI digestion followed by pulsed-field gel electrophoresis analysis. This protocol was successfully employed to construct BAC libraries from both Musa acuminata diploid [1,9] and Musa balbisiana [1, 7].

\section{Key advantages}

(a) The method was successfully used for constructing BAC libraries of both Musa acuminata and Musa balbisiana genomes and can be employed to construct BAC libraries from other Musa wild and cultivated genotypes (e.g., Cavendish).

(b) The nuclei isolation protocol here described can be used as a basis for other technologies such as Fiber-FISH (Fluorescence in situ Hybridization) and flow cytometry [7].

(c) This method enables highly efficient cloning of large fragments (up to $300 \mathrm{~kb}$ ) of banana nuclear genomic DNA. The BAC libraries from Musa acuminata and Musa balbisiana were successfully used for comparative genomics approaches with rice [1], characterizing BSV integration patterns [2], and investigating nuclear genome structure $[3,4]$.

\section{Starting material}

Approximately $30 \mathrm{~g}$ of fresh and healthy fully opened banana leaves are necessary.

\section{Time required}

Starting from banana leaf material, 9 days are required to complete the BAC library preparation: day 1 , isolation of nuclei, lysis of nuclei; day 2, test digestion conditions with Hind III, pulsed-field gel electrophoresis; day 3, large-scale Hind III digestion, pulsed-field gel electrophoresis first step; day 4, pulsed-field gel electrophoresis second step; day 5, electroelution of HMW DNA, ligation to pINDIGOBAC-5 vector; day 6 , transformation of $E$. coli with ligation mix, plating of recombinant bacteria; day 7 , pick recombinant BAC colonies, inoculation of BAC clones in 2YT liquid medium; day 8, purification of BAC DNA, digestion with NotI; day 9, pulsed-field gel electrophoresis analysis of recombinant BAC clones.

\section{Materials and methods}

\subsection{Laboratory materials}

The protocol requires:

- pulsed-field gel electrophoresis apparatus,

- centrifuge and microcentrifuge, 
- T4 DNA ligase with buffer,

- NotI, Hind III restriction enzymes with specific buffers (Gibco-BRL),

- proteinase $\mathrm{K}$,

- cell electroporator,

- pipetting material,

- agarose gel electrophoresis material,

- lambda ladder PFG marker (New England Biolabs),

- agarose plug $80 \mu \mathrm{L}$ molds (BioRad),

- InCert agarose (BMA),

- pINDIGOBAC-5 Hind III-Cloning Ready vector (Epicentre, USA),

- Gold SeaKem agarose (BMA),

- diethylether.

\subsection{Protocols}

\section{Isolation and lysis of banana nuclei}

\section{- Step 1}

Grind the leaf material in liquid nitrogen and incubate the cell extracts at $4{ }^{\circ} \mathrm{C}$ for $20 \mathrm{~min}$ in modified HB $1 \times$ buffer ( $10 \mathrm{mM}$ Tris, $10 \mathrm{mM}$ EDTA, $80 \mathrm{mM} \mathrm{KCl}, 20 \mathrm{mM} \mathrm{NaCl}$, $1 \mathrm{mM}$ spermine, $1 \mathrm{mM}$ spermidine, $45 \mathrm{mM}$ $\beta$-mercaptoethanol, $0.5 \%$ Triton $\mathrm{X}-100$, $0.5 \mathrm{M}$ sucrose, $1 \%$ of polyvinylpyrrolidone (PVP-40), 0.25\% diethylether).

Note: PVP-40 and diethylether are added to the HB extraction buffer to reduce the oxydation of polyphenolic compounds present at high levels in the banana leaf homogenate.

\section{- Step 2}

Filter leaf homogenate through a series of nylon filters $[(250,100$ and 40$) \mu \mathrm{m}$ pore diameter]. Centrifuge the cell extract at $57 \mathrm{~g}$ for $2 \mathrm{~min}$.

Note: these two steps enable separation of nuclei from cellular debris (cell wall fragments) and intact organelles (chloroplast, mitochondria).

- Step 3

Pellet the isolated nuclei by centrifugation at $850 \mathrm{~g}$ for $5 \mathrm{~min}$ and resuspend the nuclei in $1 \mathrm{~mL}$ filtered $\mathrm{HB} 1 \times$ extraction buffer without $\beta$-mercaptoethanol and PVP -40 .

- Step 4

Embed the banana nuclei in 1.2\% low-melting-point agarose plugs (InCert Agarose, BMA, Rockland, USA) by mixing an equal volume of nuclei suspension and liquefied agarose and pouring the nuclei-agarose mixture into $80-\mu \mathrm{L}$ plug molds (Bio Rad) to form agarose plugs.

\section{- Step 5}

Incubate the agarose plugs for $16 \mathrm{~h}$ at $42^{\circ} \mathrm{C}$ in $50 \mathrm{~mL}$ of Nuclei Lysis buffer (0.5 M EDTA, $1 \%$ lauroylsarcosine, $1 \mathrm{mg} \cdot \mathrm{mL}^{-1}$ proteinase $\mathrm{K}, 45 \mathrm{mM} \beta$-mercaptoethanol).

\section{- Step 6}

Inactivate residual proteinase $\mathrm{K}$ by incubating the agarose plugs in $50 \mathrm{~mL}$ of $500 \mathrm{mM}$ EDTA + 0.1 M phenylmethyl sulfonyl fluoride (PMSF) for $1 \mathrm{~h}$ at room temperature.

\section{- Step 7}

Rinse the agarose plugs in ET buffer $10 \mathrm{mM}$ Tris + 50 mM EDTA, pH 8.0, for at least $1 \mathrm{~h}$, then in TE [10:10] for an additional $2 \mathrm{~h}$ and, finally, for $1 \mathrm{~h}$ in TE [10:1] (10 mM Tris + 1 mM EDTA pH 8.0).

\section{High-molecular-weight (HMW) DNA Hind III digestion and pulsed-field gel electrophoresis (PFGE) analysis}

- Step 8

Chop the agarose plug using a sterile razor blade into small squares of approx. $0.1 \mathrm{~cm}$ and incubate the chopped plugs $(1 \mathrm{~mL}$ per agarose plug) in $1 \times$ Hind III restriction buffer (Gibco BRL, USA) with $4 \mathrm{mM}$ spermidine for $30 \mathrm{~min}$ on ice.

\section{- Step 9}

For partial digestions, add 10, 20, 30, 40 and 50 units of Hind III restriction enzyme to each chopped plug and allow the restriction enzyme to diffuse for $30 \mathrm{~min}$ on ice.

- Step 10

Incubate the Hind III digestion reactions for $15 \mathrm{~min}$ at $37^{\circ} \mathrm{C}$, then stop the activity of the Hind III restriction enzyme by adding onetenth of the total digestion volume of $0.5 \mathrm{M}$ EDTA, pH 8.0.

\section{- Step 11}

Migrate the Hind III digested agarose plugs in $1 \%$ Gold SeaKem agarose (BMA) by pulsed-field gel electrophoresis (PFGE) using the following conditions: $6 \mathrm{~V} \cdot \mathrm{cm}^{-1}, 1-$ 50-sec pulse, $16 \mathrm{~h}$, angle $120^{\circ}, 14^{\circ} \mathrm{C}$, using $0.5 \times$ TBE buffer (0.09 M Tris-borate, $0.09 \mathrm{M}$ boric acid, $0.002 \mathrm{M}$ EDTA). 


\section{Large-scale HMW DNA Hind III digestion and ligation to the pINDIGOBAC-5 vector}

\section{- Step 12}

Once the most appropriate concentration of Hind III restriction enzyme is determined, repeat preparation of agarose plugs for Hind III digestion, as described in steps 8 to 10 , using 10 agarose plugs.

- Step 13

Migrate the Hind III-digested agarose plugs in 1\% Gold SeaKem agarose (BMA) by pulsed-field gel electrophoresis (PFGE) using the following conditions: $6 \mathrm{~V} \cdot \mathrm{cm}^{-1}$, $1-50$-sec pulse, $16 \mathrm{~h}$, angle $120^{\circ}, 14^{\circ} \mathrm{C}$, using $0.5 \times$ TBE buffer $(0.09 \mathrm{M}$ Tris-borate, $0.09 \mathrm{M}$ boric acid, $0.002 \mathrm{M}$ EDTA).

- Step 14

Following electrophoresis, excise the edges of the gel containing the marker (Lambda ladder PFG marker, New England Biolabs) and a small portion of digested high-molecular-weight banana DNA and stain them with ethidium bromide. Mark the area between (100 and 300) kb.

- Step 15

Excise two portions of the gel containing banana HMW DNA ranging from (100 to 175) $\mathrm{kb}$ and (175 to 300) kb, respectively.

\section{- Step 16}

Migrate the two gel portions for a second time in $0.9 \%$ Gold SeaKem agarose (BMA) by pulsed-field gel electrophoresis (PFGE) using the following conditions: $6 \mathrm{~V} \cdot \mathrm{cm}^{-1}$, 3-sec pulse, $16 \mathrm{~h}$, angle $120^{\circ}, 14^{\circ} \mathrm{C}$, using $0.5 \times$ TBE buffer $(0.09 \mathrm{M}$ Tris-borate, $0.09 \mathrm{M}$ boric acid, $0.002 \mathrm{M}$ EDTA).

- Step 17. Cut the region of the gel containing the HMW banana DNA with a size above $100 \mathrm{~kb}$.

- Step 18

Electro-elute the HMW banana DNA from the agarose block as described by Strong et al. [8] using $100 \mu \mathrm{L} 1 \times$ TAE buffer (0.004 M Tris-acetate, $0.001 \mathrm{M}$ EDTA).

\section{- Step 19}

Recover the purified HMW DNA and estimate the concentration of the recovered banana HMW DNA in agarose gel (1\% in TAE $1 \times$ ) using dilution series of lambda DNA as a DNA concentration standard.
- Step 20

Ligate 200 ng of purified HMW banana DNA to $25 \mathrm{ng}$ of pINDIGOBAC-5 Hind III-Cloning Ready vector (Epicentre, USA) using T4 DNA ligase (Gibco-BRL) in a final volume of $100 \mu \mathrm{L}$.

\section{Analysis of recombinant BAC clones}

- Step 21

Use $1 \mu \mathrm{L}$ of the ligation to electroporate $20 \mu \mathrm{L}$ of Escherichia coli ElectroMAX DH10B cells (BRL), using a BRL Cell-Porator System according to the manufacturers' recommendations, but reducing the voltage of transformation (charge rate) from (400 to 330) V.

- Step 22

Following electroporation, resuspend the DH10B bacterial cells in $1 \mathrm{~mL}$ of SOC medium (2\% Bacto tryptone, $0.5 \%$ Bacto yeast extract, $10 \mathrm{mM} \mathrm{KCl}, 10 \mathrm{mM} \mathrm{MgCl} 2$, $10 \mathrm{mM}$ MgSO 4, $20 \mathrm{mM}$ glucose, $\mathrm{pH}$ 7.0) and incubate for $1 \mathrm{~h}$ at $37^{\circ} \mathrm{C}$ with shaking at $225 \mathrm{rpm}$.

- Step 23

Plate an aliquot of $50 \mu \mathrm{L}$ of the resuspended bacterial cells on 2YT plates containing $12.5 \mu \mathrm{g} \cdot \mathrm{mL}^{-1}$ chloramphenicol, $50 \mu \mathrm{g} \cdot \mathrm{mL}^{-1}$ $\mathrm{X}$-Gal and $25 \mu \mathrm{g} \cdot \mathrm{mL}^{-1}$ IPTG (isopropyl-thiogalactoside), and incubate at $37^{\circ} \mathrm{C}$ overnight.

- Step 24

Incubate white recombinant colonies in $10 \mathrm{~mL}$ of 2YT medium with $12.5 \mu \mathrm{g} \cdot \mathrm{mL}^{-1}$ chloramphenicol for $16 \mathrm{~h}$ at $37^{\circ} \mathrm{C}$ and isolate BAC DNA using the BAC isolation kit (Qiagen).

- Step 25

Digest 500 ng of purified BAC DNA with NotI overnight to release the BAC insert.

- Step 26

Separate the NotI-digested BAC DNA in 1\% Gold SeaKem agarose (BMA) by pulsedfield gel electrophoresis (PFGE) using the following conditions: $9 \mathrm{~V} \cdot \mathrm{cm}^{-1}, 5-15$-sec pulse, $5 \mathrm{~h}$, angle $120^{\circ}, 14^{\circ} \mathrm{C}$, using $0.5 \times$ TBE buffer (0.09 M Tris-borate, $0.09 \mathrm{M}$ boric acid, 0.002 M EDTA).

\subsection{Troubleshooting}

Two main problems can occur:

(a) Agarose plugs become brownish following incubation with lysis buffer: there is 
polyphenol contamination in the isolated nuclei.

Solutions: increase the concentration of PVP-40 and dietylether in the HB $1 \times$ nuclei extraction buffer, add $0.1 \%$ ascorbic acid to the $\mathrm{HB} 1 \times$ nuclei isolation buffer, repeat homogenate filtration and/or centrifugation at low $g$ speed (step 2).

(b) BAC DNA inserts are smaller than 100 $\mathrm{kb}$ : it is due to incorrect high-molecularweight DNA size fractionation.

Solution: Change the conditions of pulsedfield gel electrophoresis migration.

\section{Typical results obtained}

If the described protocols are followed: - pulsed-field gel electrophoresis of partially-digested HMW Musa DNA occurs (figure 1),

- the NotI digestion of Musa BAC clones (figure 2) reveals inserts on average $>100$ $\mathrm{kb}$ in size.

\section{References}

[1] Lescot M., Piffanelli P., Ciampi A.Y., Ruiz M., Blanc G., Leebens-Mack J., Da Silva F.R., Santos C.M., D'Hont A., Garsmeur O., Vilarinhos A.D., Kanamori H., Matsumoto T., Ronning C.M., Cheung F., Haas B.J., Althoff R., Arbogast T., Hine E., Pappas G.J. Jr., Sasaki T., Souza M.T. Jr., Miller R.N., Glaszmann J.C., Town C.D., Insights into the Musa genome: syntenic relationships to rice and between Musa species, BMC Genomics 9 (1) (2008) 58.

[2] Gayral P.,Noa-Carrazana J.C., Lescot M., Lheureux F., Lockhart B.E., Matsumoto T., Piffanelli P., Iskra-Caruana M.L., A single banana streak virus integration event in the banana genome as the origin of infectious endogenous pararetrovirus, J. Virol. 82 (13) (2008) 6697-6710.

[3] Cheung F., Town C.D., A BAC end view of the Musa acuminata genome, BMC Plant Biol. 7 (2007) 29.

[4] Aert R., Sági L., Volckaert G., Gene content and density in banana (Musa acuminata) as revealed by genomic sequencing of BAC clones, Theor. Appl. Genet. 109 (1) (2004) 129-39.

[5] Zhang H.B., Zhao X., Ding X., Paterson A.H., Wing R.A., Preparation of megabase-size

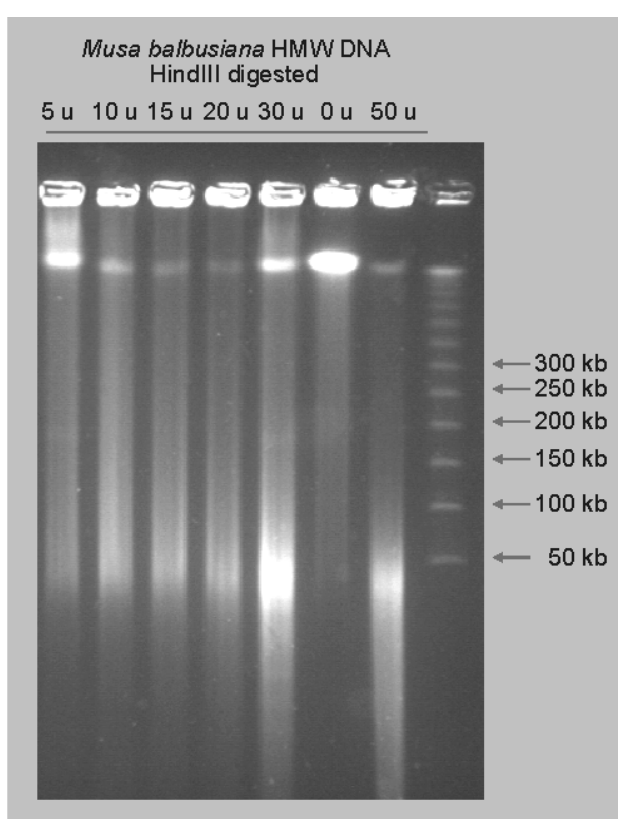

Figure 1.

PFGE analysis of partially digested Musa balbisiana HMW DNA. High-molecularweight (HMW) DNA was digested with increasing concentrations of the restriction enzyme Hind III and separated using pulsed-field gel electrophoresis (PFGE) on $1 \%$ agarose gel in $0.5 \times \mathrm{TBE}$, $6 \mathrm{~V} \cdot \mathrm{cm}^{-1}$, switch time from (1 to 50 ) sec, angle $120^{\circ}$, for $20 \mathrm{~h}$ at $14{ }^{\circ} \mathrm{C}$. The molecular weight standard is the lambda ladder PFGE marker (New England Biolabs). DNA digested with 50 units of Hind III represents a complete digestion of $\mathrm{HMW}$ DNA.

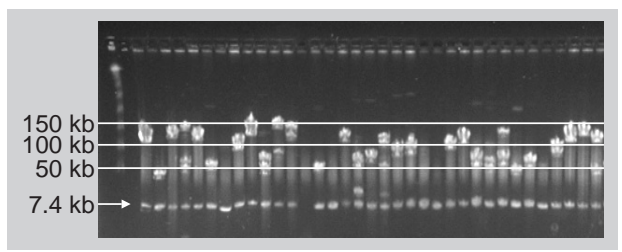

DNA from plant nuclei, Plant J. 7 (1) (1995) 175-184.

[6] Gooding P.S., Bird C., Robinson S.P., Molecular cloning and characterisation of banana fruit polyphenol oxidase, Planta 213 (5) (2001) 748-757.

[7] Safár J., Noa-Carrazana J.C., Vrána J., Bartos J., Alkhimova O., Sabau X., Simková H., Lheureux F., Caruana M.L., Dolezel J., Piffanelli P., Creation of a BAC resource to study the structure and evolution of the banana (Musa balbisiana) genome, Genome 47 (6) (2004) 1182-1191.

[8] Strong S.J., Ohta Y., Litman G.W., Amemiya C.T., Marked improvement of PAC and BAC cloning is achieved using electroelution of pulsed-field gel-separated partial digests of genomic DNA, Nucleic Acids Res. 25 (19) (1997) 3959-3961.

[9] Vilarinhos A.D., Piffanelli P., Lagoda P.L.J., Thibivilliers S., Sabau X., Carreel F., D'Hont A., Construction and characterization of a bacterial artificial chromosome library of banana (Musa acuminata Colla), Theor. Appl. Genet. 106 (6) (2003) 1102-1106.

\section{Figure 2.}

Insert size analysis of randomly chosen clones from Musa acuminata Cavendish banana BAC library. BAC DNA was digested to release insert with Notl enzyme and separated by pulsed-field gel electrophoresis (PFGE) on $1 \%$ agarose gel in $0.5 \times$ TBE, $9 \mathrm{~V} \cdot \mathrm{cm}^{-1}$, switch time from $(5$ to 15) sec, angle $120^{\circ}$, for $5 \mathrm{~h}$ at $14^{\circ} \mathrm{C}$. The DNA was stained with ethidium bromide. The molecular weight standard is the lambda ladder PFGE marker (New England Biolabs). The 7.4-kb band represents the plndigoBAC-5 Hind IIICloning Ready vector (Epicentre). 